(CC BY 4.0) | ISSN 2525-3409 | DOI: http://dx.doi.org/10.33448/rsd-v9i9.7833

Modulating effect of Poincianella bracteosa (Tul.) L.P. Queiroz bark (Leguminosae) on DNA damage induced by doxorubicin on the somatic cells of Drosophila melanogaster wings

Efeito modulador da casca de Poincianella bracteosa (Tul.) L.P. Queiroz (Leguminosae) ao dano no DNA induzido pela doxorrubicina em células somáticas das asas de

\title{
Drosophila melanogaster
}

Efecto modulador de la corteza de Poincianella bracteosa (Tul.) L.P. Queiroz

(Leguminosae) al daño del ADN inducido por doxorrubicina en células somáticas de las alas de Drosophila melanogaster

Received: 23/08/2020 | Reviewed: 30/08/2020 | Accept: 04/09/2020 | Published: 06/09/2020

Raiane de Sousa Oliveira

ORCID: https://orcid.org/0000-0001-5521-7344

Universidade Estadual do Piauí, Brasil

E-mail: raianedp2012@hotmail.com

Dallyla de Carvalho Moura

ORCID: https://orcid.org/0000-0002-4047-5938

Universidade Estadual do Piauí, Brasil

E-mail: dallylacarvalho84@gmail.com

Regina Maria Silva Sousa

ORCID: https://orcid.org/0000-0002-6300-0361

Universidade Estadual do Piauí, Brasil

E-mail: reginasousa484@gmail.com

Thais Teixeira da Silva

ORCID: https://orcid.org/0000-0002-0788-326X

Universidade Estadual do Piauí, Brasil

E-mail: thaisteixeiradsilva@gmail.com

Maria das Dores Alves Oliveira

ORCID: https://orcid.org/0000-0002-2847-6567

Instituto Federal de Educação, Ciência e Tecnologia do Piauí, Brasil

E-mail: maralves013@gmail.com 
Joaquim Soares da Costa Júnior

ORCID: https://orcid.org/0000-0002-9849-201X Instituto Federal de Educação, Ciência e Tecnologia do Piauí, Brasil E-mail: Jquimjr@ifpi.edu.br

Pedro Marcos de Almeida ORCID: https://orcid.org/0000-0001-5431-6818 Universidade Estadual do Piauí, Brasil

E-mail: pedromarcosalmeida@yahoo.com.br Francielle Alline Martins ORCID: https://orcid.org/0000-0002-0113-8023 Universidade Estadual do Piauí, Brasil E-mail: francielle@ccn.uespi.br

\begin{abstract}
The aim of this study was to assess the genotoxic and antigenotoxic effects of Poincianella bracteosa bark aqueous extract on DNA damage induced by doxorubicin (DXR) a chemotherapeutic agent using SMART (Somatic Mutation and Recombination Test). The analysis was performed using the somatic mutation and recombination test in Drosophila melanogaster. Larvae from the standard and high-bioactivity crosses were chronically treated with four concentrations of $P$. bracteosa bark tea, alone and in association with DXR. The results revealed no mutagenic effect of bark extract for any of the concentrations tested. A modulating effect of aqueous extract in reducing the genotoxic action of DXR was observed for all concentrations tested in descendants of both crosses, but inhibition was more effective in those from the high-bioactive cross. The modulating effect observed may be associated with the presence of tannins and reducing sugars, as observed in phytochemical studies, since they are capable of capturing and stabilizing free radicals. Given the widespread use of P. bracteosa bark in folk medicine, further studies to elucidate the mechanism of action of these cellular compounds and with other experimental models would be useful to confirm that $P$. bracteosa extract is beneficial to human health.
\end{abstract}

Keywords: Antimutagenic; Catingueira; Medicinal plant; SMART.

\title{
Resumo
}

O objetivo deste estudo foi avaliar os efeitos genotóxicos e antigenotóxicos do extrato aquoso da casca de Poincianella bracteosa sobre o dano ao DNA induzido pela doxorrubicina (DXR), 
um agente quimioterápico, usando o SMART (Teste de Mutação e Recombinação Somática). As análises foram realizadas usando o teste de mutação recombinação somática em Drosophila melanogaster. Larvas dos cruzamentos padrão e de alta bioatividade foram tratadas cronicamente com quatro concentrações de chá de casca de P. bracteosa, sozinho e em associação com a DXR. Os resultados não revelaram efeito mutagênico do extrato de casca para nenhuma das concentrações testadas. Um efeito modulador do extrato aquoso na redução da ação genotóxica da DXR foi observado para todas as concentrações testadas, em descendentes de ambos os cruzamentos, mas a inibição foi mais efetiva naqueles do cruzamento de alto bioatividade. $\mathrm{O}$ efeito modulador observado pode estar associado à presença de taninos e açúcares redutores, como observado em estudos fitoquímicos, uma vez que são capazes de capturar e estabilizar radicais livres. Dada ampla utilização da casca de P. bracteosa na medicina popular, novos estudos para elucidar o mecanismo de ação desses compostos celulares e com outros modelos experimentais seriam úteis para confirmar que o extrato de P. bracteosa é benéfico à saúde humana.

Palavras-chave: Antimutagênico; Catingueira; Planta medicinal; SMART.

\section{Resumen}

El objetivo de este estudio fue evaluar los efectos genotóxicos y antigenotóxicos del extracto acuoso de la corteza de Poincianella bracteosa sobre el daño del ADN inducido por doxorrubicina (DXR), un agente quimioterapéutico, utilizando SMART (Prueba de Recombinación y Mutación Somática). El análisis se realizó mediante la prueba de mutación y recombinación somática en Drosophila melanogaster. Las larvas de cruces estándar y altamente bioactivos se trataron crónicamente con cuatro concentraciones de té de corteza de P. bracteosa, solo y en combinación con DXR. Los resultados no revelaron un efecto mutagénico del extracto de corteza para ninguna de las concentraciones probadas. Se observó un efecto modulador del extracto acuoso en la reducción de la acción genotóxica de la DXR para todas las concentraciones ensayadas, en descendientes de ambos cruces, pero la inhibición fue más efectiva en los del cruzamiento con alta bioactividad. El efecto modulador observado puede estar asociado a la presencia de taninos y azúcares reductores, como se observa en estudios fitoquímicos, ya que son capaces de capturar y estabilizar radicales libres. Dado el amplio uso de la corteza de $P$. bracteosa en la medicina popular, nuevos estudios para dilucidar el mecanismo de acción de estos compuestos celulares y con otros modelos experimentales serían útiles para confirmar que el extracto de P. bracteosa es beneficioso para la salud humana. Palabras clave: Antimutagénico; Catingueira; Planta medicinal; SMART. 


\section{Introduction}

Plants have been used for medicinal purposes for thousands of years, ranging from the simplest treatment forms to the industrial manufacture of drugs (Saraiva et al., 2015). According to the World Health Organization (WHO), around $80 \%$ of the world's population still depends on medicinal plants for basic health care, with increasing use observed in Western countries (Ouedraogo et al., 2012). In Brazil, around $80 \%$ of the population use medicinal plant-based products. However, the lack of suitable information on the safety of these products has hindered more widespread use of these plants (Vargas et al., 2016).

Medicinal plants, the most common source of phytochemicals, exhibit a number of biological activities, such as antimicrobial, antifungal (Nguta et al., 2016), antimalarial (Kiraithe, Nguta, Mbaria, \& Kiama, 2016) and bioinsecticidal (Bosire, Deyou, Kabaru, Kimata, \& Yenesew, 2014). Pharmacological screening, isolation and characterization of bioactive compounds, as well as toxicological and clinical assessment are essential to guarantee their effectiveness and determine their pharmacokinetics, bioavailability, safety and drug interactions (Sasidharan, Chen, Saravanan, Sundram, \& Latha, 2011).

Poincianella bracteosa (Tul.) L.P. Queiroz. (Fabaceae), popularly known as "pau-derato" (rat's stick) and/or "catingueira" is an endemic plant to Brazil, found in the Caatinga and Cerrado biomes (Maia-Silva, Silva, Hrncir, Queiroz, \& Imperatriz-Fonseca, 2012) and distributed in the North (Tocantins state), Northeast (Bahia, Ceará, Maranhão, Paraíba, and Piauí) and Midwest (Goiás and Mato Grosso) of the country (Lewis, 2015).

$P$. bracteosa has been widely used in popular medicine for different therapeutic purposes. The bark (decoction and/or infusion) is used to treat kidney, liver and intestinal infections, gastritis, hypertension, diarrhea, bronchitis, prostate infection, flatulence and indigestion (Monteiro, Alburquerque \& Araújo, 2005). Leaves and bark are used to treat catarrhal infections, diarrhea, gas, intestinal cramps, hepatitis and anemia. The flowers are used for colds, the flu and constipation (Silva et al., 2015).

Twice-daily leaf infusion of $P$. bracteosa is used against gas and indigestion (Chaves \& Barros, 2012) while bark immersed in cachaça (distilled spirit made from fermented sugarcane juice) is considered an aphrodisiac (Castro \& Cavalcante, 2011). Despite its widespread use, phytochemical studies are incipient, to date revealing only the presence of tannins in the bark (Monteiro, Souza, Neto, Scopel, \& Trindade, 2014) and phenolic compounds in the roots (Cruz, Carvalho, Silva, Gualberto, \& Macedo, 2015). 
In spite of the therapeutic advantages, the different chemical constituents present in $P$. bracteosa can be potentially toxic, mutagenic and carcinogenic (Ping, Darah, Yusuf, Yeng, \& Sasidharan, 2012). Thus, assessment of the toxic effects of any medicinal plant extract for short and long-term human consumption is extremely important. Furthermore, assessing the toxicity, mutagenicity and genotoxicity of natural products is a crucial step for pharmaceutical companies to consider new therapeutic agents (Sponchiado et al., 2016).

A biological model successfully used in genotoxicity studies is Drosophila melanogaster. It is estimated that nearly $75 \%$ of disease-related genes in humans have functional orthologs in the fly. In general, flies and humans share about 80 to $90 \%$ identity in functional protein domains (Pandey \& Nichols, 2011). As such, these organisms have been used to study the genotoxic and antigenotoxic activities of many medicinal plants (Patenkovic, Stamenkovic-Radak, Nikolic, Markovic, \& Andelkovic, 2013; Zafred et al., 2016).

The somatic mutation and recombination test (SMART) in D. melanogaster can detect a wide spectrum of genetic end points, including point mutations, deletions and certain chromosomal abnormalities, as well as mitotic recombination and gene conversion (Graf, Abraham, Rincón, \& Würgler, 1998). Considering the sensitivity of the SMART and the use of P. bracteosa in traditional medicine, the present study aimed to assess the phytochemical content, genotoxic and modulatory potential of its stem bark extract, alone or combined with doxorubicin, using this test.

\section{Methodology}

\subsection{Plant Material}

The bark of $P$. bracteosa was collected from an adult plant in Teresina, Piaui (Northeast

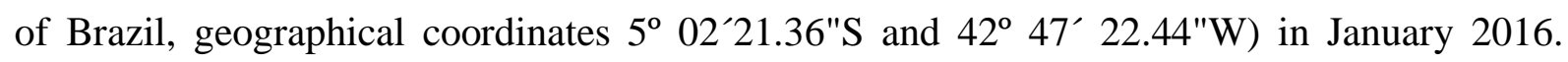
Herbarium specimens containing leaves, flowers and fruits were stored in the Afrânio Fernandes Herbarium at the State University of Piauí (UESPI, Teresina - PI, Brazil; voucher specimen number HAF 03635). The bark was oven dried at $45-50^{\circ} \mathrm{C}$ and then ground in a blender until a fine powder was obtained. Around four grams of the powder was added to 250 $\mathrm{mL}$ of distilled water and boiled for 10 minutes. Next, the aqueous extract of P. bracteosa $(\mathrm{AEPb})$ was filtered and maintained in a refrigerator at $4^{\circ} \mathrm{C}$, in a dark jar for $24 \mathrm{~h}$. The extract was assessed at four concentrations: 2, 4, 8 and $16 \mathrm{mg} / \mathrm{mL}$. The phytochemical profiles of the 
(CC BY 4.0) | ISSN 2525-3409 | DOI: http://dx.doi.org/10.33448/rsd-v9i9.7833

extracts were determined by colorimetric reactions that qualitatively detect the primary plant metabolites (Barbosa et al., 2004).

\subsection{Doxorubicin}

Doxorubicin (DXR, Doxolen® lyophilized, Eurofarma Laboratórios Ltda., São Paulo, Brazil, CAS No. 23214-92-8), dissolved in distilled water in the dark at a concentration of 0.125 $\mathrm{mg} / \mathrm{mL}$ was used as positive control, and distilled water as negative control. DXR is a chemotherapeutic agent that induces single and double-stranded DNA breaks (Rezende et al. 2011).

\subsection{Drosophila Strains and Crosses}

Three strains of D. melanogaster were used: 1) multiple wing hairs: $y$; $m w h j$ ( $m w h, 3$ 0.3); 2) flare-3 (flr3, 3-38.8) (flr3/In(3LR)TM3, ri pp sep I(3)89Aabx34e and Bd ${ }^{S}$ ); 3) ORR/ ORR; flr3/In(3LR)TM3, ri pp sep I(3)89Aabx34e and $B d^{S}$. To produce the standard (ST) cross, virgin females were collected from stocks of flare-3 and crossed with multiple wing hair ( $m w h)$ males (Graf U \& Singer, 1989). The high bioactivation (HB) cross, with high cytochrome P450 levels, was obtained by crossing ORR; flare-3 virgin females with $m w h$ males (Graf \& Schaik, 1992).

\subsection{Larval Feeding}

For the treatments and controls, 72h-old larvae from the ST and HB crosses were transferred to plastic tubes containing $4 \mathrm{~g}$ of instant mashed potatoes (Yoki®), dissolved in 12 $\mathrm{mL}$ of a solution containing $\mathrm{AEPb}$ with or without $\mathrm{DXR}$ at $0.125 \mathrm{mg} / \mathrm{mL}$. The larvae were fed on the medium until the larval phase was complete (about 2 days). The experiments were performed at $25^{\circ} \mathrm{C}$ and $60 \%$ relative humidity.

\subsection{Analysis of Adult Flies}

After hatching, individual adult flies were collected and stored in $70 \%$ ethanol. Both crosses produced experimental progeny that consisted of marker-heterozygous $(\mathrm{MH})$ flies $(m w h$ $+/+$ flare-3) with phenotypically wild-type wings, and balancer-heterozygous $(\mathrm{BH})$ flies ( $m w h$ 
+/+ TM3 Bds) with phenotypically serrate wings. The wings of $\mathrm{MH}$ flies were removed, mounted in Faure's solution, and examined for spots using a compound microscope at 400X magnification. During the analysis, the positions of the spots were recorded according to wing sections (Graf et al., 1984). Single spots resulted from point mutations, chromosomal abnormalities, or recombination events, while twin spots (flare and $m w h$ ) were produced by somatic recombination between the proximal marker flare and the centromere of chromosome 3 (Pereira, Antunes, Graf, \& Spanó, 2008).

\subsection{Statistical Analysis}

The binomial conditional test was used to evaluate mutagenic potential (Frei \& Würgler, 1988). The study compares the number of different classes of spots found between treatments and their negative control. For antimutagenic analysis, the frequencies of each type of spot for each treatment group were submitted to pairwise comparison (DXR vs AEPb + DXR in each class analyzed), using the nonparametric Mann-Whitney U-test and Wilcoxon rank sum test (Frei \& Würgler, 1995). The inhibition percentages of stem bark tea were calculated using the frequency of clones per $10^{5}$ cells, corrected by the control, as follows: [(DXR alone $-\mathrm{AEPb}+$ DXR/ DXR alone) x 100] (Abraham, 1994).

\section{Results}

Both crosses (ST and HB) were supplied with third instar larvae at concentrations ranging from 2 to $16 \mathrm{mg} / \mathrm{mL}$ for approximately $48 \mathrm{~h}$. The frequency of positive control spots showed a statistically significant increase in all categories when compared to the negative control $(\mathrm{p}<0.05)$.

When the data on different $\mathrm{AEPb}$ concentrations were compared with the negative control, no statistically significant $(\mathrm{p}>0.05)$ differences were found in total number of spots, small single spots, large single spots or twin spots in either ST or HB crosses. The results indicate that $\mathrm{AEPb}$ showed no direct genotoxic effect, based on the analysis of ST crosses, or indirect genotoxic effect, according to HB crosses, on the somatic cells of D. melanogaster (Table 1). 
Table 1. Summary of results obtained in the marked trans-heterozygous descendants $(\mathrm{MH})$ of Drosophila melanogaster derived from the standard (ST) and high bioactivation (HB) crosses treated with different aqueous extract of Poincianella bracteosa $(\mathrm{AEPb})$ concentrations separately, positive control (DXR $0.125 \mathrm{mg} / \mathrm{mL}$ ) and negative control (distilled water).

\begin{tabular}{|c|c|c|c|c|c|c|c|c|}
\hline \multirow{2}{*}{\multicolumn{2}{|c|}{$\begin{array}{l}\text { Treatments } \\
(\mathrm{mg} / \mathrm{mL})\end{array}$}} & \multirow{3}{*}{$\mathbf{N}$} & \multicolumn{4}{|c|}{ Spots per fly (number of spots) statistical diagnosis ${ }^{\mathrm{a}}$} & \multirow{3}{*}{$\begin{array}{l}\text { Spots } \\
\text { with } \\
m w h \\
\text { clone } \\
\text { (n) }\end{array}$} & \multirow{3}{*}{$\begin{array}{c}\text { Frequency of } \\
\text { clone } \\
\text { formation } / 10^{5} \\
\text { cells per } \\
\text { cell division }{ }^{\mathrm{d}, \mathrm{e}}\end{array}$} \\
\hline & & & \multirow{2}{*}{$\begin{array}{c}\text { Small single } \\
\text { spots } \\
(1-2 \text { cells })^{b} \\
\text { m=2 }\end{array}$} & \multirow{2}{*}{$\begin{array}{c}\text { Large single } \\
\text { spots } \\
(>2 \text { cells) })^{\mathrm{b}} \\
\mathbf{m = 5}\end{array}$} & \multirow{2}{*}{$\begin{array}{c}\text { Twin spots } \\
\qquad=5\end{array}$} & \multirow{2}{*}{$\begin{array}{l}\text { Total spots } \\
\qquad \mathbf{m}=\mathbf{2}\end{array}$} & & \\
\hline DXR & $\mathbf{A E P b}$ & & & & & & & \\
\hline \multicolumn{9}{|c|}{ Standart Cross } \\
\hline $\mathbf{0}$ & $\mathbf{0}$ & 20 & $0.40(8)$ & $0.05(1)$ & $0.00(0)$ & $045(0)$ & 8 & 0.82 \\
\hline 0.125 & $\mathbf{0}$ & 20 & $7.30(146)+$ & $1.60(32)+$ & $0.30(6)+$ & $9.20(184)+$ & 171 & $17.52[16.70]$ \\
\hline $\mathbf{0}$ & 2 & 20 & $0.45(9)-$ & $0.05(1) \mathrm{i}$ & $0.00(0) \mathrm{i}$ & $0.50(10)-$ & 9 & $1.02[0.20]$ \\
\hline $\mathbf{0}$ & 4 & 20 & $0.30(6)-$ & $0.00(0) \mathrm{i}$ & $0.00(0) \mathrm{i}$ & $0.35(7)-$ & 7 & $0.72-[0.10]$ \\
\hline $\mathbf{0}$ & 8 & 20 & $0.40(8)-$ & $0.00(0) \mathrm{i}$ & $0.00(0) \mathrm{i}$ & $0.45(9)$ - & 8 & $0.82[0.00]$ \\
\hline $\mathbf{0}$ & 16 & 20 & $0.45(9)-$ & $0.00(0) \mathrm{i}$ & $0.00(0) \mathrm{i}$ & $0.45(9)-$ & 9 & $0.92[0.10]$ \\
\hline \multicolumn{9}{|c|}{ High Bioactivation Cross } \\
\hline $\mathbf{0}$ & $\mathbf{0}$ & 20 & $0.45(09)$ & $0.00(00)$ & $0.00(0)$ & $0.45(09)$ & 9 & 0.92 \\
\hline 0.125 & $\mathbf{0}$ & 20 & $5.00(100)+$ & $3.00(60)+$ & $0.60(12)+$ & $8.60(172)+$ & 162 & $16.60[15.68]$ \\
\hline 0 & 2 & 20 & $0.05(01)-$ & $0.05(01) \mathrm{i}$ & $0.00(0) \mathrm{i}$ & $0.10(02)-$ & 2 & $0.20-[0.72]$ \\
\hline $\mathbf{0}$ & 4 & 20 & $0.05(01)-$ & $0.00(00) \mathrm{i}$ & $0.00(0) \mathrm{i}$ & $0.05(01)-$ & 1 & $0.10-[0.82]$ \\
\hline 0 & 8 & 20 & $0.10(02)-$ & $0.05(01) \mathrm{i}$ & $0.00(0) \mathrm{i}$ & $0.15(03)-$ & 3 & $0.31-[0.61]$ \\
\hline 0 & 16 & 20 & $0.40(08) \mathrm{i}$ & $0.45(09)+$ & $0.00(0) \mathrm{i}$ & $0.85(17) \mathrm{i}$ & 17 & $1.74[0.82]$ \\
\hline
\end{tabular}

${ }^{\text {a }}$ Statistical diagnoses, probability levels: -, negative; + , positive; i, inconclusive; m: minimal risk multiplication factor for the assessment of negative results; significance levels $\alpha=\beta=0.05$ vs. negative control (distilled water).

b Including rare single flr3 spots.

${ }^{\mathrm{c}}$ Considering the $m w h$ clones for the single spots and $m w h$ for the twin spots.

${ }^{\mathrm{d}}$ Frequency of clone formation: clones/flies/48,800 cells (without size correction).

e Numbers in square brackets are induction frequencies corrected for spontaneous incidence estimated from negative controls.

$\mathrm{N}=$ number of flies

Source: Research data.

Table 2 shows the modulating effect of co-treatment with different concentrations of $\mathrm{AEPb}$ and DXR $(0.125 \mathrm{mg} / \mathrm{mL})$, obtained by analyzing MH descendants from ST and HB crosses. The data show statistically significant reductions $(\alpha=0.05)$ in both crosses (ST and HB) in the frequencies of small single spots and total spots when compared to the positive control. 
Table 2. Summary of results obtained in the marked trans-heterozygous descendants (MH) of Drosophila melanogaster derived from the standard (ST) and high bioactivation (HB) crosses treated with different aqueous extract of Poincianella bracteosa $(\mathrm{AEPb})$ concentrations in combination with DXR, positive control (DXR $0.125 \mathrm{mg} / \mathrm{mL}$ ) and negative control (distilled water).

\begin{tabular}{|c|c|c|c|c|c|c|c|c|c|}
\hline \multirow{2}{*}{\multicolumn{2}{|c|}{$\begin{array}{c}\text { Treatments } \\
(\mathrm{mg} / \mathrm{mL})\end{array}$}} & \multirow{3}{*}{$\mathbf{N}$} & \multicolumn{4}{|c|}{ Spots per fly (number of spots) statistical diagnosis ${ }^{a}$} & \multirow{3}{*}{$\begin{array}{c}\text { Spots } \\
\text { with } \\
m w h \\
\text { clone }^{\mathrm{c}} \\
\text { (n) }\end{array}$} & \multirow{3}{*}{$\begin{array}{c}\text { Frequency } \\
\text { of clone } \\
\text { formation } / 1 \\
0^{5} \text { cells per } \\
\text { cell } \\
\text { division }^{\mathrm{d}, \mathrm{e}} \\
\end{array}$} & \multirow{3}{*}{$I(\%)^{\mathrm{f}}$} \\
\hline & & & \multirow{2}{*}{$\begin{array}{l}\text { Small single } \\
\text { spots } \\
(1-2 \text { cells })^{b}\end{array}$} & \multirow{2}{*}{$\begin{array}{c}\text { Large } \\
\text { single } \\
\text { spots } \\
(>2 \text { cells })^{b}\end{array}$} & \multirow{2}{*}{$\begin{array}{l}\text { Twin } \\
\text { spots }\end{array}$} & \multirow{2}{*}{ Total spots } & & & \\
\hline DXR & $\mathbf{A E P b}$ & & & & & & & & \\
\hline \multicolumn{10}{|c|}{ Standart Cross } \\
\hline $\mathbf{0}$ & $\mathbf{0}$ & 20 & $0.40(8)$ & $0.05(1)$ & $0.00(0)$ & $0.45(9)$ & 8 & 0.82 & \\
\hline 0.125 & $\mathbf{0}$ & 20 & $7.30(146)+$ & $1.60(32)+$ & $0.30(6)+$ & $9.20(184)+$ & 171 & $17.52[16.70]$ & 55.21 \\
\hline 0.125 & 2 & 20 & $2.10(42)^{*}$ & $1.80(36)$ & $0.20(4)$ & $4.10(82)^{*}$ & 81 & $8.30[7.48]$ & 55.21 \\
\hline 0.125 & 4 & 20 & $1.80(36)^{*}$ & $2.20(44)$ & $0.00(0)$ & $4.00(80)^{*}$ & 80 & 8.20 [7.38] & 55.81 \\
\hline 0.125 & 8 & 20 & $1.00(20)^{*}$ & $0.70(14)$ & $0.05(1)$ & $1.75(35)^{*}$ & 34 & 3.48 [2.66] & 84.07 \\
\hline 0.125 & 16 & 20 & $1.00(20)^{*}$ & $0.95(19)$ & $0.15(3)$ & $2.10(42)^{*}$ & 42 & $4.30[3.48]$ & 79.16 \\
\hline \multicolumn{10}{|c|}{ High Bioactivation Cross } \\
\hline $\mathbf{0}$ & $\mathbf{0}$ & 20 & $0.45(9)$ & $0.00(0)$ & $0.00(0)$ & $0.45(09)$ & 9 & 0.92 & \\
\hline 0.125 & $\mathbf{0}$ & 20 & $5.00(100)+$ & $3.00(60)+$ & $0.60(12)+$ & $8.60(172)+$ & 162 & 16.60 [15.68] & \\
\hline 0.125 & 2 & 20 & $1.10(22)^{*}$ & $1.30(26)^{*}$ & $0.15(3)$ & $2.55(51)^{*}$ & 46 & 4.71 [3.79] & 71.60 \\
\hline 0.125 & 4 & 20 & $0.70(14)^{*}$ & $0.40(8)^{*}$ & $0.05(1)$ & $1.15(23)^{*}$ & 22 & $2.25[1.33]$ & 86.42 \\
\hline 0.125 & 8 & 20 & $0.60(12)^{*}$ & $0.10(2)^{*}$ & $0.00(0)$ & $0.70(14)^{*}$ & 13 & $1.33[0.41]$ & 91.98 \\
\hline 0.125 & 16 & 20 & $1.10(22)^{*}$ & $0.55(11)^{*}$ & $0.15(3)$ & $1.80(36)^{*}$ & 34 & $3.48[2.56]$ & 79.01 \\
\hline
\end{tabular}

${ }^{\text {a }}$ Statistical diagnoses, probability levels: -, negative; +, positive; i, inconclusive; $p<0.05$ vs. negative control (distilled water) and *p $<0.05$ vs. DXR only.

${ }^{\mathrm{b}}$ Including rare single flr 3 spots.

${ }^{\mathrm{c}}$ Considering the $m w h$ clones for the single spots and $m w h$ for the twin spots.

${ }^{\mathrm{d}}$ Frequency of clone formation: clones/flies/48,800 cells (without size correction).

${ }^{\mathrm{e}}$ Numbers in square brackets are induction frequencies corrected for spontaneous incidence estimated from negative controls.

${ }^{\mathrm{f}}$ Inhibition (\%): calculated as [(DXR alone $-\mathrm{AEPb}+\mathrm{DXR} / \mathrm{DXR}$ alone $\left.) \times 100\right]^{30}$.

$\mathrm{N}=$ number of flies

Source: Research data.

$\mathrm{AEPb}$ showed a reduction in the number of mutant spots in $m w h$ clones for all concentrations of AEPb + DXR $(0.125 \mathrm{mg} / \mathrm{mL})$, suggesting a modulating effect on the DNA damage caused by doxorubicin in somatic cells of the imaginal discs of $D$. melanogaster. All the concentrations tested inhibited DXR-induced damage, with an inhibitory effect ranging between $55.21 \%$ and $91.98 \%$ for the different concentrations, with no concentration-dependent relationship. In this case, comparison of co-treatments involving $\mathrm{AEPb}$ plus $\mathrm{DXR}$ $(0.125 \mathrm{mg} / \mathrm{mL})$ showed no statistical significance between them $(\mathrm{p}<0.05)$ (data not shown).

A phytochemical study was carried out on $\mathrm{AEPb}$, indicating the presence of hydrolyzed tannins and reducing sugars. 


\section{Discussion}

In the present study, the potential effects of $\mathrm{AEPb}$ alone or in combination with the chemotherapeutic agent DXR were tested in chronic treatments on larval descendants of ST and $\mathrm{HB}$ crosses, using the somatic mutation and recombination test (SMART) in $D$. melanogaster. Similar studies have been carried out to assess medicinal aqueous plant extracts (Fernandes et al., 2013, Jacociunas et al., 2014).

The concentrations used in this study were initially based on satisfactory results in genotoxic and cytotoxic tests in meristematic cells from the Allium cepa root, where the extract of $P$. bracteosa also showed no cytotoxic or genotoxic effects since the number of chromosomal changes did not increase (Souza et al., 2016).

The negative control contained a low number of spontaneous mutations in both crosses, and the positive control exhibited a statistically significant increase in the number of mutations compared to the negative control. This validates the use of the SMART test and demonstrates its good response to the mutagenic agent DXR, which is consistent with data in the literature (Guterres et al., 2013, Vale et al., 2013).

In the experimental conditions assessed, in addition to showing no mutagenic/recombinogenic effect, $\mathrm{AEPb}$ exhibited a modulatory response in doxorubicin activity. This response was observed in the descendants of both crosses (ST and HB), but inhibition was more effective in those of the HB cross, similar to the results reported in the literature (Fernandes et al., 2014).

The difference between ST and HB crosses is related to the level of CYP450. Descendants from the former cross contain basal levels of CYP450, while those of the latter showed high CYP450 enzyme expression. This set of enzymes is involved in the metabolism of a wide variety of endogenous and xenobiotic compounds. Some drugs are inactivated through this biotransformation; however, the active properties of certain metabolites generated in this process may increase (Saturnino, Machado, Lopes, \& Nepomuceno, 2018), explaining the higher modulating effect of $\mathrm{AEPb}$ in $\mathrm{HB}$ cross offspring.

The mechanisms by which AEPb reduces the frequency of DXR-induced mutant spots were not directly evaluated in this study. However, it is known that DXR binds strongly to DNA due to its ability to intersperse between pairs of bases, causing ruptures in the molecule and inhibiting DNA and RNA synthesis (Orsolin, Oliveira, \& Nepomuceno, 2016).

Moreover, the cytotoxic effect of DXR is due to its transformation into semiquinone free radicals, leading to cell death from DNA damage (Felício et al., 2011). Thus, AEPb can be 
considered an antimutagenic agent that, when combined with DXR, acts as a DXR-induced free radical scavenger and/or by blocking its interaction with DNA.

The presence of hydrolyzed tannins and reducing sugars may explain the lower number of mutant stains produced by AEPb when associated with DXR. Hydrolyzed tannins consist of gallic acid esters and glycolyzed ellagic acids, formed from shikimate, where the sugar hydroxyl groups are esterified with phenolic acids (Monteiro et al., 2005). Reducing sugars are carbohydrates that contain a free carbonyl group, capable of oxidizing in the presence of oxidative agents in an alkaline solution (Santos et al., 2017). Both can capture and stabilize free radicals, thereby promoting a preventive effect on the carcinogenic process and other degenerative diseases associated with high intercellular concentrations of free radicals (Vale et al., 2013).

The action of $\mathrm{AEPb}$ modulation observed in this study may serve as the basis for the development of new coadjuvant drugs in chemotherapy, given that the combined use of extracts with modulatory action can decrease the genotoxic effect of cancer drugs on healthy cells without interfering in the treatment of tumor cells (Felício et al., 2011).

\section{Conclusion}

The present study shows that aqueous bark extract did not induce mutation and when associated with DXR, at all concentrations, the extract exhibited a modulating effect on chemotherapy-induced DNA damage in the somatic cells of Drosophila melanogaster wings. Although promising, further studies the genotoxicity with other experimental models are needed to confirm that $P$. bracteosa extract is beneficial to human health, since this plant is widely used in folk medicine.

\section{Acknowledgments}

The authors would like to thank the Universidade Estadual do Piauí (UESPI) for providing the infrastructure for this study and the Programa Institucional de Bolsas de Iniciação Científica (PIBIC-UESPI) for granting a research scholarship. We thank Dr. Francisco Soares Santos Filho for species identification. 


\section{References}

Abraham, S. K. (1994). Antigenotoxicity of coffee in the Drosophila assay for somatic mutation and recombination. Mutagenesis, 9(4), 383-386. https://doi.org/10.1093/mutage/9.4.383

Barbosa, W. L. R, Quignard, E., Tavares, I. C. C., Pinto, L. N., Oliveira, F. Q., \& Oliveira, R. M. (2004). Manual para Análise fitoquímica e Cromatografia de Extratos Vegetais (Edição Revisada). Revista Científica da UFPA 4. Recuperado de http://www.ufpa.br/rcientifica.

Bosire, C. M., Deyou, T., Kabaru, J. M., Kimata, D. M. \& Yenesew, A. (2014). Larvicidal activities of the stem bark extract and rotenoids of Millettia usaramensis subspecies usaramensis on Aedes aegypti L. (Diptera: Culicidae). Journal of Asia-Pacific Entomology, 17, 531-535. https://doi.org/10.1016/j.aspen.2014.05.003

Castro, A. S. F., \& Cavalcante, A. M. B. (2011). Flores da Caatinga. Campina Grande: Instituto Nacional do Semiárido, 30-31.

Chaves, E. M. F., \& Barros, R. F. M. (2012). Diversidade e uso de recursos medicinais do carrasco na APA da Serra da Ibiapaba, Piauí, Nordeste do Brasil. Revista Brasileira de Plantas Medicinais, 14(3), 476-486. http://dx.doi.org/10.1590/S1516-05722012000300009

Cruz, R. C. D., Carvalho, K. S., Silva, S. L. C., Gualberto, S. A., \& Macedo, G. E. L. (2015). Bioatividade da raíz de Poincianella bracteosa (Tul.) L. P. Queiroz (Fabaceae) sobre larvas do Aedes aegypti (Linnaeus, 1762) (Diptera: Culicidae). Revista Brasileira de Biociências, 13 (4), 259-264. Recuperado em:http://www.ufrgs.br/seerbio/ojs/index.php/rbb/article/view/3399

Felício, L. P., Silva, E. M., Ribeiro, V., Miranda, C. T., Vieira, I. L. B. F., Passos, D. C. S., Ferreira, A. K. S., Vale, C. R., Lima, D. C. S., Carvalho, W. B., \& Nunes, W. B. (2011). Mutagenic potential and modulatory effects of the medicinal plant Luehea divaricata (Malvaceae) in somatic cells of Drosophila melanogaster: SMART/wing. Genetics and Molecular Researh, 10(1), 16-24. https://doi.org/10.4238/vol10-1gmr982

Fernandes, F. H., Guterres, Z. R., Garcez, W. S., Lopes, S. M., Corsino, J., \& Garcez, F. G. (2014). Assessment of the (anti)genotoxicity of brown propolis extracts from Brazilian Cerrado 
biome in a Drosophila melanogaster model. Food Research International, 62, 20-26. https://doi.org/10.1016/j.foodres.2014.02.029

Fernandes, L. M., Garcez, W. S., Mantovani, M. S., Figueiredo, P. O., Fernandes, C. A., Garcez, F. R., \& Guterres, Z. R. (2013). Assessment of the in vitro and in vivo genotoxicity of extracts and indole monoterpene alkaloid from the roots of Galianthe thalictroides (Rubiaceae). Food and Chemical Toxicology, 59, 405-411. https://doi.org/10.1016/j.fct.2013.05.052

Franchi, L. P., Guimarães, N. N., Andrade, L. R., Andrade, H. H. R., Lehmann, M., Dihl, R. R., \& Cunha, K. S. (2013). Antimutagenic and antirecombinagenic activities of noni fruit juice in somatic cells of Drosophila melanogaster. Anais da Academia Brasileira de Ciências, 85(2), 585-594. https://doi.org/10.1590/S0001-37652013000200008

Frei, H., \& Würgler, F. E. (1995). Optimal experimental design and simple size for the statistical evaluation of data from somatic mutation and recombination tests (SMART) in Drosophila. Mutatation Research, 334(2), 247-258. https://doi.org/10.1016/0165-1161(95)90018-7

Frei, H., \& Würgler, F. E. (1988). Statistical methods to decide whether mutagenicity test data from Drosophila assays indicate a positive, negative, or inconclusive result. Mutation Research, 203(4), 297-308. https://doi.org/10.1016/0165-1161(88)90019-2

Graf, U., Abraham, S. K., Rincón, J. G., \& Würgler, F. E. (1998). Antigenotoxicity studies in Drosophila melanogaster. Mutation Research/Fundamental and Molecular Mechanisms of Mutagenesis, 402(1-2), 203-209. https://doi.org/10.1016/S0027-5107(97)00298-4

Graf, U., \& Singer, D. (1989). Somatic mutation and recombination test in Drosophila melanogaster (wing-spot test): Effects of extracts of airborne particulate matter from fireexposed and non-fire-exposed building ventilation filters. Chemosphere, 19(7), 1094-1097. https://doi.org/10.1016/0045-6535(89)90533-X

Graf, U., \& Van Schaik, N. (1992). Improved high bioactivation cross for the wing somatic mutation and recombination test of Drosophila melanogaster. Mutation Research, 271(1), 5967. https://doi.org/10.1016/0165-1161(92)90032-H 
Graf, U., Wügler, F. E., Katz, A. J., Frei, H., Juon, H., Hall, C. B., \& Kale, P. G. (1984). Somatic mutation and recombination test in Drosophila melanogaster. Environmental Mutagenesis, 6(2), 153-188. https://doi.org/10.1002/em.2860060206

Guterres, Z. R., Silva, A. F. G., Garcez, W. S., Garcez, F. R., Fernandes, C. A., \& Garcez, F. R. (2013). Mutagenicity and recombinagenicity of Ocotea acutifolia (Lauraceae) aporphinoid alkaloids. Mutation Research, 757(1), 91-96. https://doi.org/10.1016/j.mrgentox.2013.07.004

Jacociunas, L. V., Dihl, R. R., Lehmann, M., Ferraz, A. B. F., Richter, M. F., Silva, J., \& Andrade, H. H. R. (2014). Effects of artichoke (Cynara scolymus) leaf and bloom head extracts on chemically induced DNA lesions in Drosophila melanogaster. Genetics and Molecular Biology, 37(1), 93-104. https://doi.org/10.1590/S1415-47572014000100015

Kiraithe, M. N., Nguta, J. M., Mbaria, J. M., \& Kiama, S. G. (2016). Evaluation of the use of Ocimum suave Willd. (Lamiaceae), Plectranthus barbatus Andrews (Lamiaceae) and Zanthoxylum chalybeum Engl. (Rutaceae) as antimalarial remedies in Kenyan folk medicine. Journal of Ethnopharmacology, 178, 266-271. https://doi.org/10.1016/j.jep.2015.12.013

Lewis, G. P. (2015). Poincianella in Lista de Espécies da Flora do Brasil. (Jardim Botânico do Rio de Janeiro). Recuperado de: http://floradobrasil.jbrj.gov.br/jabot/floradobrasil/FB109774

Maia-Silva, C., Silva, C. I., Hrncir, M., Queiroz, R. T., \& Imperatriz-Fonseca, V. L. (2012). Guia de plantas: visitadas por abelhas na Caatinga ( $1^{\mathrm{a}}$ ed.). Fortaleza: Fundação Brasil Cidadão. Recuperado de https://www.mma.gov.br/estruturas/203/_arquivos/livro_203.pdf

Monteiro, J. M., Alburquerque, U. P., \& Araújo, E. L. (2005). Taninos: uma abordagem da química à ecologia. Química Nova, 28(5), 892-896. https://doi.org/10.1590/S010040422005000500029

Monteiro, J. M., Souza, J. S. N., Neto, E. M. F. L., Scopel, K., \& Trindade, E. F. (2014). Does total tannin content explain the use value of spontaneous medicinal plants from the Brazilian semi-arid region? Revista Brasileira de Farmacognosia, 24(2), 116-123. https://doi.org/10.1016/j.bjp.2014.02.001 
Nguta, J. M., Opong, R. A., Nyarko, A. K., Manu, D. Y., Addo, P. G. A., Otchere, I., \& Twum, K. (2016). Antimycobacterial and cytotoxic activity of selected medicinal plant extracts. Journal of Ethnopharmacology, 182, 10-15. https://doi.org/10.1016/j.jep.2016.02.010

Orsolin, P. C., Oliveira, R. G. S., \& Nepomuceno, J. C. (2016). Modulating effect of simvastatin on the DNA damage induced by doxorubicin in somatic cells of Drosophila melanogaster. Food and Chemical Toxicology, 90, 10-17. https://doi.org/10.1016/j.fct.2016.01.022

Ouedraogo, M., Baudoux, T., Stévigny, C., Nortier, J., Colet, J. M., Efferth, T., Qu, F., Zhou, J., Chan, K., Shaw, D., Pelkonen, O., \& Duez, P. (2012). Review of current and "omics" methods for assessing the toxicity (genotoxicity, teratogenicity and nephrotoxicity) of herbal medicines and mushrooms. Journal of Ethnopharmacology, 140(3), 492-512. https://doi.org/10.1016/j.jep.2012.01.059

Pandey, U. B., \& Nichols, C. D. (2011). Human Disease Models in Drosophila melanogaster and the Role of the Fly in Therapeutic Drug Discovery. Pharmacological Reviews, 63(2), 411436. https://doi.org/10.1124/pr.110.003293

Patenkovic, A., Stamenkovic-Radak, M., Nikolic, D., Markovic, T., \& Andelkovic, M. (2013). Synergistic effect of Gentiana lutea L. methyl methanesulfonate genotoxicity in the Drosophila wing spot test. Journal of Ethnophrmacology, 146(2), 632-636. https://doi.org/10.1016/j.jep.2013.01.027

Pereira, D. G., Antunes, L. M. G., Graf, U., \& Spanó, M. A. (2008). Protection by Panax ginseng C.A. Meyer against the genotoxicity of doxorubicin in somatic cells of Drosophila melanogaster. Genetic and Molecular Biology, 31(4), 947-955. https://doi.org/10.1590/S141547572008000500024

Ping, K. Y., Darah, I., Yusuf, U. K., Yeng, C., \& Sasidharan, S. (2012). Genotoxicity of Euphorbia hirta: An Allium cepa Assay. Molecules, 17, 7782-7791. https://doi.org/10.3390/molecules 17077782

Rezende, A. A. A., Silva, M. L. A., Tavares, D. C., Cunha, W. R., Rezende, K. C. S., Bastos, J. K., Lehmann, M., de Andrade, H. H. R., Guterres, Z. R., Silva, L. P., \& Spanó, M. A. (2011). 
The effect of the dibenzylbutyrolactolic lignan (-)-cubebin on doxorubicin mutagenicity and recombinogenicity in wing somatic cells of Drosophila melanogaster. Food and Chemical Toxicology, 49(6), 1235-1241. https://doi.org/10.1016/j.fct.2011.03.001

Santos, A. A., Deoti, J. R., Müller, G., Dário, M. G., Stambuk, B. U., \& Junior, S. L. A. (2017). Dosagem de açúcares redutores com o reativo DNS em microplaca. Brazilian Journal of Food Technology, 20. https://doi.org/10.1590/1981-6723.11315

Saraiva, M. E., Ulisses, A. V., Ribeiro, D. A., Oliveira, L. G., Macêdo, D. G., Sousa, F. F., Menezes, I. R., Sampaio, E. V., Souza, M. M. (2015). Plant species as a therapeutic resource in areas of the savanna in the state of Pernambuco, Northeast Brazil. Journal of Ethnopharmacology, 171, 141-153. https://doi.org/10.1016/j.jep.2015.05.034

Sasidharan, S., Chen, Y., Saravanan, D., Sundram, K. M. \& Latha, L. Y. (2011). Extraction, isolation and characterization of bioactive compounds from plants' extracts. African Journal of Traditional, Complementary and Alternative Medicines, 8(1). https://doi.org/10.4314 /ajtcam.v8i1.60483

Saturnino, R. S., Machado, N. M., Lopes, J. C., \& Nepomuceno, J. C. (2018). Assessment of the mutagenic, recombinogenic, and carcinogenic potential of amphotericin B in somatic cells of Drosophila melanogaster. Drug and Chemical Toxicology, 41(1), 9-15. https://doi.org/10.1080/01480545.2016.1188302

Silva, J. D. A., Nascimento, M. G. P., Grazina, L. G., Castro, K. N. C., Mayo, S. J. \& Andrade, I. M. (2015). Ethnobotanical survey of medicinal plants used by the community of Sobradinho, Luís Correia, Piauí, Brazil. Journal of Medicinal Plants Research, 9(32), 872-883. https://doi.org/ 10.5897/JMPR2015.5881

Sponchiado, G., Adam, M. L., Silva, C. D., Soley, B. S., Sampayo, C. M., Cabrini, D. A., Correr, C. J., Otuki MF. (2016). Quantitative genotoxicity assays for analysis of medicinal plants: A systematic review. Journal of Ethnopharmacology, 178, 289-296. https://doi.org/ 10.1016 / j.jep.2015.10.026 
Vale, C. R., Silva, C. R., Oliveira, C. M. A., Silva, A. L., Carvalho, S. \& Chen, L. C. (2013). Assessment of toxic, genotoxic, antigenotoxic, and recombinogenic activities of Hymenaea courbaril (Fabaceae) in Drosophila melanogaster and mice. Genetics and Molecular Research, 12(3), 2712-2724. http://dx.doi.org/10.4238/2013.July.30.9

Vargas, F. S., Almeida, P. D. O., Boleti, A. P. A., Pereira, M. M., Souza, T. P., Vasconcellos, M. C., Nunez, C. V., Pohlit, A. M., Lima, E. S. (2016). Antioxidant activity and peroxidase inhibition of Amazonian plants extracts traditionally used as anti-inflammatory. $B M C$ Complementary and Alternative Medicine, 16(83). https://doi.org/10.1186/s12906-016-1061-9

Zafred, R. R. T., Spano, M. A., Martins, G. R., Figueiredo, C. C. M., Ferreira, P. C., Silva, L. P. \& Silva, R. M. G. (2016). Pro-oxidant activity and genotoxicity of the Astronium fraxinifolium using wings SMART and Allium cepa Test. Research Journal of Medicinal Plants, 10(4), 276-285. https://doi.org/10.3923/rjmp.2016.276.285

\title{
Percentage of contribution of each author in the manuscript
}

\author{
Raiane de Sousa Oliveira $-30 \%$ \\ Dallyla de Carvalho Moura - $20 \%$ \\ Regina Maria Silva Sousa - 10\% \\ Thaís Teixeira da Silva - 5\% \\ Maria das Dores Alves Oliveira - 10\% \\ Joaquim Soares da Costa Júnior - 5\% \\ Pedro Marcos de Almeida - 5\% \\ Francielle Alline Martins - 15\%
}

